\title{
Machine-Readable Files for Serials Management: An Optimizing Program and Use Data
}

\section{Maurita Peterson Holland}

The unending battle to balance the serials budget within the larger information resources budget has provoked much thought (and many faculty members!). All too frequently the subjective measure of serials "value" is applied by librarians or faculty. This is done either by the librarian and serials personnel subjectively ranking the relative (perceived) worth of titles (value $=$ rank) or surveying students and faculty, allowing them to make subjective evaluations of titles. There are, however, also some objective measures of value that may be employed. These include measuring value by the proportion of time a title spends off the shelf (sample shelves at random times, continue sampling until a sufficient database is established), by surveying students and faculty, inquiring which titles they use and how frequently, or by tallying the frequency with which a title is used (i.e., uses/year). In an earlier article $^{1}$ a formula was presented, based on use and patron access time, which measures the effect of serials budget reductions on public service. The files of data created in order to apply that formula can also be used for other kinds of objective serials budget analyses. Here we will describe such analyses and present their application in a large engineering collection.

\section{SERIALS \\ CLASSIFICATION AND DATA COLLECTION}

Most serials collections can be classified as shown in figure 1 . In an ongoing data collection process for all serials, use both within the library and through circulation is tallied as the items are reshelved. For each of the components of the serials collection, we then create machine-readable files which provide management information. Data elements are: title, years of subscription if a non-current title, language if non-English, unbound and bound use, call number, cost.

The classification of serials, also considered data files, with description of file contents and action, is given below:

Non-Current Titles (dead or canceled): Action-collect data, sort by usage, consider resubscribing to those with high usage, storing those with low use.

Current, Non-Free Titles: Action-collect data, (1) sort by "density, " obtain an optimal list of titles for budget (2) sort by subject, then by use or "density" within each area.

Current Free Titles: Action-collect data, sort by usage, cut those with minimal usage if space is a consideration.

Recently Acquired Titles: Action-collect data for a few years before considering as "current, non-free" titles, make subjective cuts as felt necessary.

"Sacred Cows" (titles which the library "must" have): Action-don't touch "sacred cows."

Because current, non-free titles are the prime target for serials reductions, we will consider action both on the optimal list and the use sort by subject.

\section{OPTIMAL LIST}

Using a heuristic device that generates feasible solution to a special type of integer programming problem known as the "knapsack" problem, we perform the following:

1. Establish a value for each item (title)

Maurita Peterson Holland is head, Technology Libraries, and lecturer, College of Engineering, University of Michigan, Ann Arbor. The author gratefully acknowledges the expert programming help of John Ryder and Douglas Holbrook, seniors at the UM College of Engineering. 


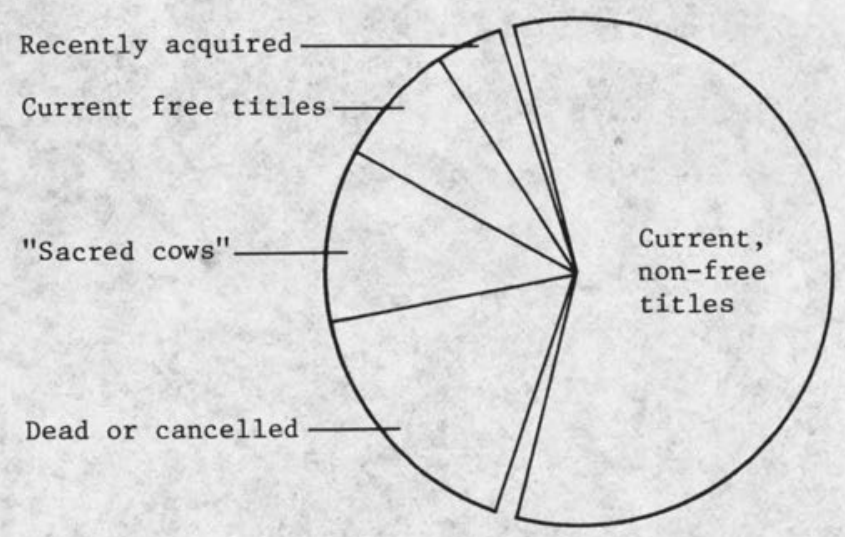

FIGURE 1

Serials Collection Classification

in the problem (value is defined here as the average number of unbound uses per year per title).

2. Divide this value by the cost for each title, giving value/dollar/title = density:

$$
\text { density }=\frac{\text { value }}{\text { cost }}
$$

3. Sort the collection of current, nonfree titles in descending order using the density obtained above. By generating a list of titles, sorted by density, it is possible to obtain an optimal list of titles for any desired budget. Such a list might appear as follows:

$\begin{array}{lclc}\text { Title } & \text { Cost } & \text { Budget } & \text { Density } \\ \text { GGG } & \mathrm{C}_{1} & \mathrm{C}_{1} & 27 \\ \text { MMM } & \mathrm{C}_{2} & \mathrm{C}_{1}+\mathrm{C}_{2} & 22 \\ \vdots & \vdots & \vdots & \cdot \\ \vdots & \vdots & \vdots & \cdot \\ \text { BBB } & \mathrm{C}_{n} & \sum_{i=1}^{n} \mathrm{C}_{i} & .5\end{array}$

To obtain an optimal list, one reads down the list until reaching the appropriate budget. The titles above that point comprise the optimal list.

Applying this procedure to our own data, we created a machine-readable file of all serials titles in our collection which have received one or more uses in the last five years (1,700 titles) and sorted on the current, non-free files. (See figure 2.)
Fifty percent of our use was met by 114 of the 1,092 titles in the current, non-free title including several titles new during the past five years. (Interface Age, two years; Petroleum Engineering International, three years ...)

\section{Observations}

The optimal list ranks the low-cost, high-use volumes near the top of the list. In engineering, this includes titles the research faculty may prefer not to have support such as Creative Computing, Motor Trend, Byte, Aviation Week and Space Technology, etc. If these titles are important for non-research use in the library, they could be defined as "sacred cows" and thus removed from the file; more typically, however, the "sacred cows" are those titles representing scholarly proceedings and transactions from professional societies. More than half of the titles which were in the lowest 10 percent of use were new during the last one to four years. It is possible that a combination of low faculty/student awareness of the title, and an indexing lag or lack thereof, accounts for their low use. Therefore, we decided to exempt most new subscriptions from cancellation for five years.

\section{USE BY SUBJECT}

A list of titles is generated by engineering discipline. Each list is subarranged by use, based on 1976-81 use data; the earli- 


$\quad$ TITLE
Civil Engineering
ACM
Interface Age
Engin. News Record
Petroleum Engin. Int'1
\[ \]
Warme und Stoffuber
Soil Mechanics \&
Foundation Engin.
Rail International
Polymer Science USSR

CALL NO.

TA1

QA 76

QA75

TA 1

TN 860

QC 251

TA 710

TP 2

TP986

DENSITY
19.85
12.66
12.50
12.47
11.66
.
0.02
0.02
0.02
0.02

FIGURE 2

Example of File

$\begin{array}{cc}\text { BUDGET } & \text { SERVICE\% } \\ \$ 7.00 & 1.07 \% \\ \$ 10.00 & 1.36 \% \\ \$ 22.00 & 1.82 \% \\ \$ 45.00 & 4.04 \% \\ \$ 51.00 & 4.36 \% \\ \vdots & . \\ \$ 40,162.00 & . \\ & 95.55 \% \\ \$ 40,437.00 & \\ \$ 40,508.00 & 95.60 \% \\ \$ 40,888.00 & 95.60 \% \\ & 95.67 \%\end{array}$

\section{CHEMICAL ENGINEERING}

Chemical and Engineering News

$$
\begin{array}{r}
1975 / 76 \text { UB/B } \\
208 / 89
\end{array}
$$

1980/81 UB/B

$150 / 115$

Chemical Engineering Progress

$$
\text { 1975/76 UB/B }
$$

$109 / 97$

Hydrocarbon Processing

$$
\begin{array}{r}
1975 / 76 \mathrm{UB} / \mathrm{B} \\
57 / 129
\end{array}
$$

AICHe Journal

$$
\begin{array}{r}
1975 / 76 \text { UB/B } \\
82 / 137
\end{array}
$$

$1980 / 81 \mathrm{UB} / \mathrm{B}$
$100 / 129$

1980/81 UB/B

$69 / 158$

1980/81 UB/B

$22 / 119$

Management Science

$$
\begin{array}{r}
1975 / 76 \mathrm{UB} / \mathrm{B} \\
58 / 142
\end{array}
$$

CIVIL ENGINEERING

Engineering News Record.

$$
\begin{array}{r}
1975 / 76 \mathrm{UB} / \mathrm{B} \\
389 / 123
\end{array}
$$

Civil Engineering (ASCE)

$$
\begin{array}{rr}
1975 / 76 \text { UB/B } & 1980 / 81 \mathrm{UB} / \mathrm{B} \\
142 / 57 & 112 / 73
\end{array}
$$

1980/81 UB/B

$30 / 62$

$$
\text { 1980/81 UB/B }
$$

$330 / 177$

American Concrete Institute. Journal.

$$
\begin{array}{rr}
1975 / 76 \mathrm{UB} / \mathrm{B} & 1980 / 81 \mathrm{UB} / \mathrm{B} \\
57 / 78 & 16 / 68
\end{array}
$$

ASCE Structural Division Journal

$$
\begin{array}{rr}
1975 / 76 \mathrm{UB} / \mathrm{B} & 1980 / 81 \mathrm{UB} / \mathrm{B} \\
28 / 106 & 6 / 127
\end{array}
$$

Journal of Materials Science.

$$
\text { 1975/76 UB/B }
$$

$105 / 53$

NAVAL ENGINEERING

$1980 / 81$ UB/B
$23 / 88$

1980/81 UB/B

$79 / 111$
1976 Price

$\$ 8.00$

1976 Price

$\$ 75.00$

1976 Price

$\$ 4.00$

1976 Price $\$ 75.00$

1976 Price $\$ 32.00$

1976 Price $\$ 12.00$

1976 Price $\$ 7.00$

1976 Price $\$ 11.00$

1976 Price

$\$ 7.00$

1976 Price

$\$ 191.00$

1976 Price $\$ 10.00$
Aver.

bd. and unbound use*

$\begin{array}{rrr}\begin{array}{r}1981 \text { Price } \\ \$ 40.00\end{array} & \text { TP } 1 & 306 \\ 1981 \text { Price } & \text { TP } 1 & 230 \\ \$ 100.00 & & \end{array}$

1981 Price TP 692 $\$ 7.00$

1981 Price $\$ 100.00$

TP 1

1981 Price $\$ 50.00$

HD 28

1981 Price $\$ 23.00$

TA 1

1981 Price

TA 1

232

$\$ 7.00$

1981 Price

TA 680

150

$\$ 25.00$

1981 Price

TA 1

138

$\$ 15.00$

1981 Price

TA 401

114

$\$ 436.00$

1981 Price $\$ 15.00$

"This figure is calculated over five years data in file, not just on the two printed out. 
Shipping World \& Shipbuilder. Reserve.

1975/76 UB/B

$60 / 70$

Motor Ship. London. 1975/76 UB/B

$82 / 55$

Shipbuilding and Marine Engineering International. 1975/76 UB/B $121 / 8$

$103 / 17$

$1981 \mathrm{UB} / \mathrm{B}$

$47 / 47$
1976 Price

$\$ 26.00$

1976 Price

$\$ 16.00$

1976 Price

$\$ 14.00$

1976 Price

$\$ 0.00$
1981 Price

$\$ 58.00$

1981 Price

$\$ 48.00$

1981 Price

$\$ 40.00$

1981 Price

$\$ 0.00$
VM 1

VM 1

VM 1

V 1

FIGURE 3, CONTINUED

Example of File

est and most recent prices are printed out. (See figure 3.) This file is especially useful in discussion with faculty and in facilitating departmental input on cancellation decisions.

\section{FURTHER USES}

The serials file in machine-readable form has many other uses. For example, the subject file aids in maintaining balance by discipline throughout the collection when cutting the serials budget.

Public service uses are especially important. Our reference librarians use the data to point out most-used titles in a particular subject discipline as students come in with the assignment to become familiar with literature in their field. A new user education tool is created when the file is enhanced by the addition of the indexing or abstracting tool for each title. Also included is information on which titles can be searched online through the use of DIALOG, Orbit, BRS, etc. Another enhancement is the special issue information, such as "January issue includes product directory."

\section{SERIALS MANAGEMENT}

No single list or algorithm will resolve all problems in the complex effort to provide the greatest number of patrons the most convenient access to the serial literature they require within allotted budget. However, applying our public service formula of 1976 and creating the optimizing program and discipline use sort provides objective information that can aid judicious decision making.

\section{REFERENCE}

1. Maurita Peterson Holland, "Serials Cuts vs. Public Service: A Formula," College \& Research Libraries 37:543-48 (Nov. 1976). 

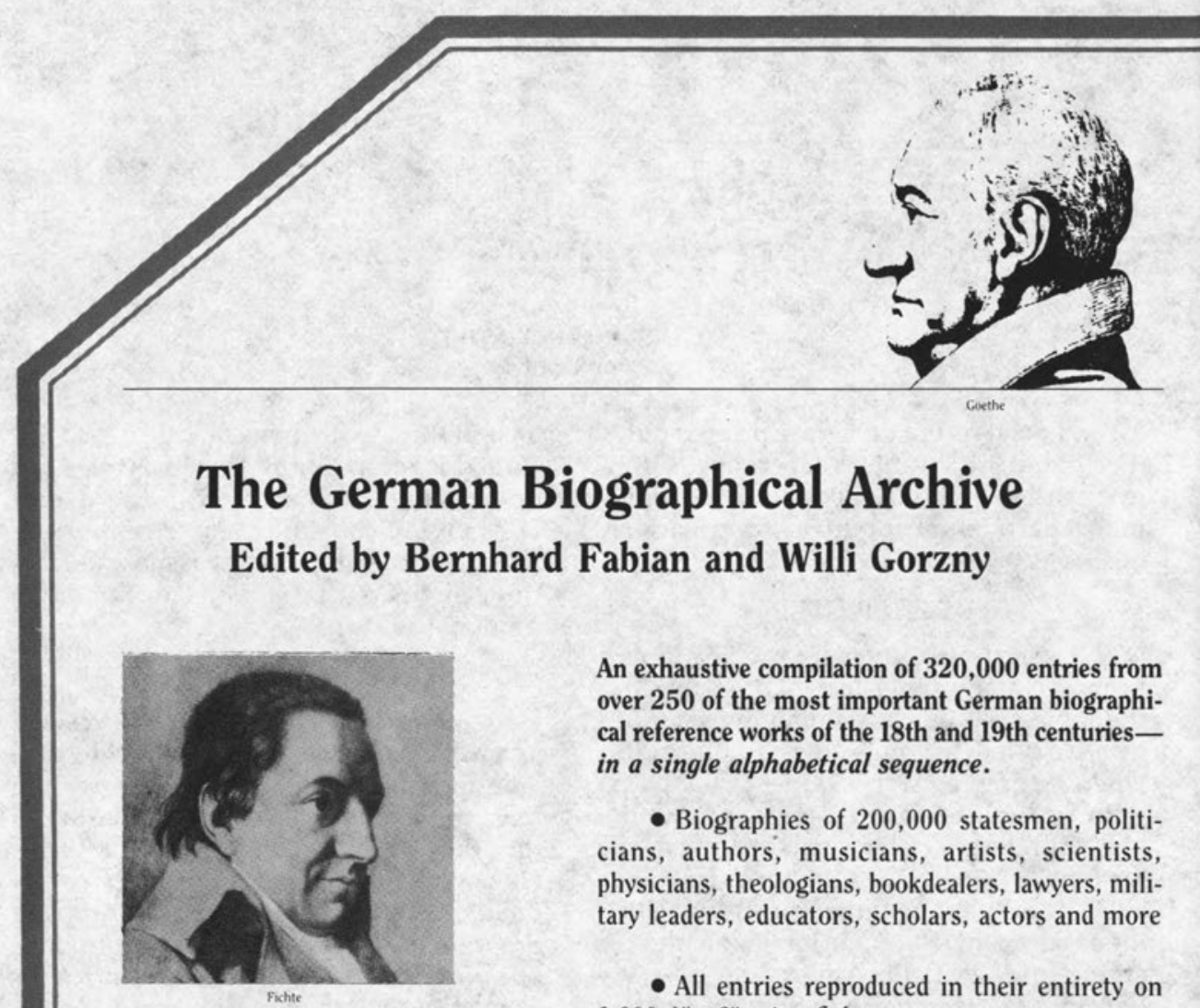

An exhaustive compilation of 320,000 entries from over 250 of the most important German biographical reference works of the 18 th and 19 th centuriesin a single alphabetical sequence.

- Biographies of 200,000 statesmen, politicians, authors, musicians, artists, scientists, physicians, theologians, bookdealers, lawyers, military leaders, educators, scholars, actors and more

- All entries reproduced in their entirety on $1,0004^{\prime \prime} \times 6^{\prime \prime}$ microfiche

- Comprehensive printed bibliography of the reference works with a detailed index to the individuals

In the 18th and 19th centuries German scholars compiled numerous biographical reference works still valuable for the wealth of information they provide. No library in the world holds more than $50 \%$ of the material contained in the Archive. 
The editors have painstakingly selected the reference sources to provide geographical, historical and occupational details about the individuals included in the cumulated fiche edition. The enormous editorial contribution and the abundance of information now readily available make The German Biographical Archive an unparalleled research tool for the study of the history and culture of the German-speaking realm.
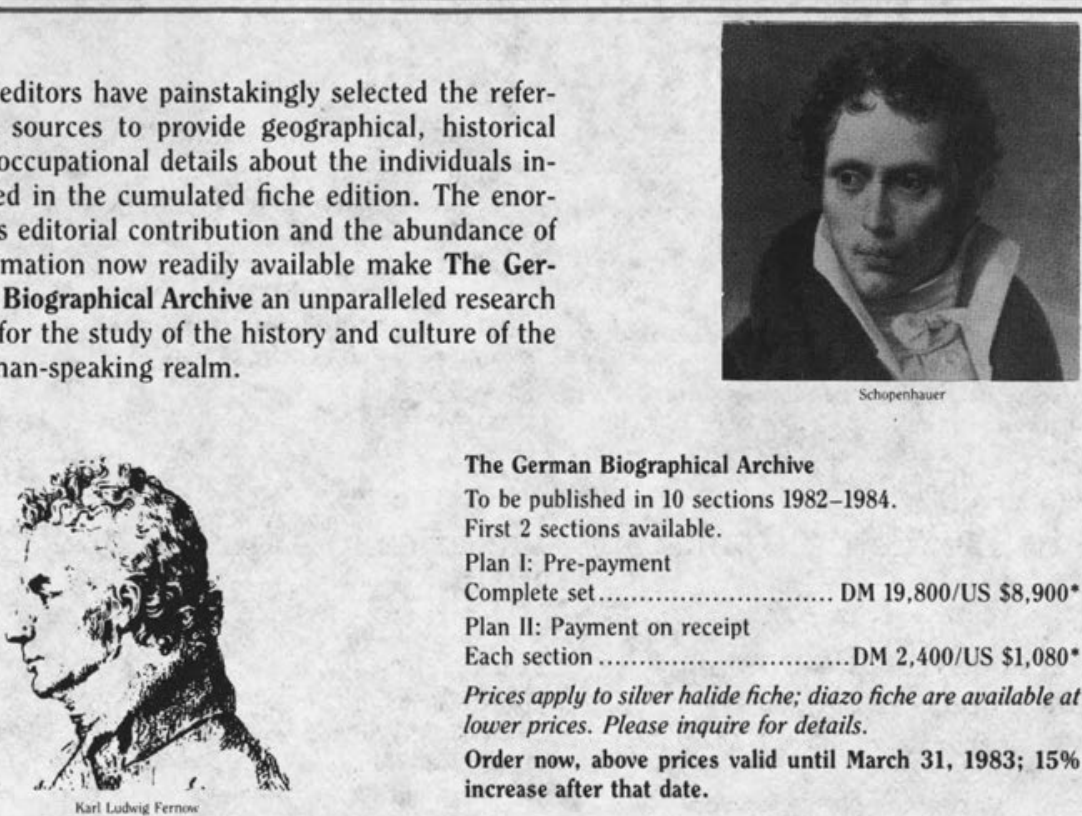

The German Biographical Archive

To be published in 10 sections 1982-1984.

First 2 sections available.

Plan I: Pre-payment

Complete set.

DM $19,800 /$ US $\$ 8,900^{*}$

Plan II: Payment on receipt

Each section

DM $2,400 /$ US $\$ 1,080^{*}$

Prices apply to silver halide fiche; diazo fiche are available at lower prices. Please inquire for details.

Order now, above prices valid until March 31,$1983 ; 15 \%$ increase after that date.

\section{Now complete-}

\section{The Marburger Index}

Over 500,000 remarkable photographs of fine arts in Germany from the Middle Ages to the present from the collections of the Bildarchiv Foto Marburg and the Rheinisches Bildarchiv in Cologne.

$\mathbf{5 , 0 0 0}$ silver fiche.
.US $\$ 6,675^{*}$

\section{Index Photographique} de l'Art en France

More than 100,000 rare photographs of French art and architecture. A companion to The Marburger Index with exceptional coverage of sacred medieval architecture and sculpture.

1,000 silver fiche...

US $\$ 3,000^{*}$

- Dollar prices are approximations based on prevailing exchange rates. For exact prices, please inquire.

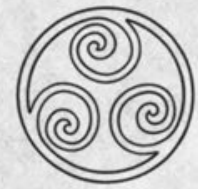

Exclusive agents in the U.S. \& Canada:

Cleanwater Publishing Company, Inc.

1995 Broadway, New York, N.Y. 10023

Cleanwater Publishing Company of Canada

231 Hollyberny Trail, Willowdale, Ontario M2H 2P3

K.G. Saur Verlag 


\section{IMPORTANT TITLES IN LIBRARIANSHIP}

Reference Services and Library Education

Essays in Honor of Frances Neel Cheney edited by Edwin S. Gleaves, Vanderbilt University, and John Mark Tucker, Purdue University

Provides detailed descriptions of state-of-theart bibliographic instruction, networking, computer-assisted reference services, and current trends in the field.

320pp. ISBN 0-669-05320-1

$\$ 29.95$

\section{Maritime Boundary Delimitation}

An Annotated Bibliography

Ted L. McDorman, Kenneth P. Beauchamp, and Douglas M. Johnston

A Dalhousie Ocean Studies Programme Book The first in its field, this bibliography includes the entire range of English-language books, monographs, and articles published since World War II.

ISBN 0-669-06146-8

January 1983

\section{The Lexington Books Special Series in Libraries and Librarianship}

The Parliament of Great Britain:

\section{A Bibliography}

Robert U. Goehlert and Fenton S. Martin, Indiana University

A complete bibliography of the social, political, and economic histories of Great Britain and their relationships with the development of Parliament. Includes over 2200 citations.

240pp. ISBN 0-669-05700-2 \$24.95

\section{Prizewinning Books for Children}

Themes and Stereotypes in U.S. Prizewinning Prose Fiction for Children

Jaqueline Schachter Weiss, Temple University This overview of children's fiction, divided into genres, discusses stereotypes and the kinds of themes children prefer. Appendix lists prizewinners by year and award.

ISBN 0-669-06352-5

February 1983
The Public Library in the 1980s

The Problems of Choice

Lawrence J. White, New York University Identifies the segments of the population who use the public library most, examines public opinion, and explores conventional and alternative methods of funding, technological developments, service to special groups, and other challenges and policies.

ISBN 0-669-06342-8

January 1983

\section{The Feminization of Librarianship} in France

A Silent Revolution

Mary Niles Maack, University of Minnesota Utilizes the results of archival research and personal interviews to provide an in-depth history of the feminization of the French library profession.

ISBN 0-669-06368-1

Spring 1985

\section{An Introduction to the World of Children's Books}

Margaret R. Marshall

A Grafton Book

Discusses trends in the area and provides a guide to evaluation, selection, and promotion in libraries.

190pp.

$$
\text { code 05806-8 }
$$

\section{The Librarians' Glossary and} Reference Book

Of Terms Used in Librarianship,

Documentation and the Book Crafts Fourth Revised Edition

L. M. Harrod, National Library, Singapore A Grafton Book

904pp.

code 05795-9

LexingtonBooks, D. C. Heath and Company 